\title{
Biotechnology a Modern Tool for Fruits Production - A Review
}

\author{
Anuradha $^{1 *}$, Subhash Chander ${ }^{2}$ and Arvind Malik ${ }^{1}$ \\ ${ }^{1}$ Department of Horticulture, CCS Haryana Agricultural University, \\ Hisar-125004, Haryana, India \\ ${ }^{2}$ Division of Fruit Crops, ICAR-IIHR, Bangalore-560089, Karnataka, India \\ *Corresponding author
}

\begin{tabular}{|c|c|}
\hline \multicolumn{2}{|r|}{ A B S T R A C T } \\
\hline & \multirow{6}{*}{$\begin{array}{l}\text { The problem of long juvenility, incompatibility and sterility are the biggest hindrances for } \\
\text { the improvement of fruit crops through conventional fruit breeding. To mitigate the biotic } \\
\text { and abiotic stresses, improvement is desired in already cultivated cultivar for one or few } \\
\text { traits. In that regard, the biotechnological tools will prove quite useful to expedite the rate } \\
\text { of fruit crop improvement. For production of quality planting material by tissue culture is } \\
\text { commercialized in banana and strawberry. Biotechnological tools such as somaclonal } \\
\text { variation and in vitro mutagenesis are the choicest method for varietal development in } \\
\text { banana. GCTCV-119 and Novaria are the result of somaclonal variation and in vitro } \\
\text { mutagenesis, respectively. Somatic hybridization has been explored for the rootstock and } \\
\text { scion improvement of citrus. Somatic hybridization research of almost two decades in } \\
\text { citrus is yielding fruit now. Embryo rescue has helped in accelerating the pace of } \\
\text { stenospermocarpic grape improvement and 'Sweet Scarlet' and 'Thomcord' are two of the } \\
\text { seedless table grapevines, which were released using this technique. Transgenic variety } \\
\text { Rainbow and Sun Up carrying resistance to PRSV are being commercially cultivated in } \\
\text { Hawaii of USA. With the introduction of concept of cisgenics, the genetically transformed } \\
\text { fruits are likely to get public acceptance. Molecular marker aid great help in early } \\
\text { diagnosis of sex of dioecious fruit plant like date palm and papaya. Presently marker } \\
\text { linked to resistance for Dagger nematode and pierce disease at university of California in } \\
\text { the breeding programs are routinely used for grapevine rootstock improvement. Genome } \\
\text { sequencing has unveiled the mystery about various genes, the phylogenetic relationship } \\
\text { and evolution history of sequenced fruit crop. }\end{array}$} \\
\hline Keywords & \\
\hline & \\
\hline Article Info & \\
\hline & \\
\hline & \\
\hline
\end{tabular}

\section{Introduction}

The requirement of fruits is increasing proportionally with the increasing population. Although conventional plant breeding techniques have made considerable progress in the development of improved varieties, they have not been able to keep pace with the increasing demand for fruits. Therefore an immediate need is felt to integrate biotechnology to speed up the crop improvement programmes. Biotechnological tools have revolutionized the entire crop improvement programmes by providing new strains of plants, supply of planting material, more efficient and selective pesticides and improved fertilizers. Fruit crops are conventionally propagated through cutting, budding, grafting, layering etc. but these techniques are time consuming and cumbersome. Plant tissue culture provides an effective measure of such problems of fruit 
crop multiplication. There is need of efficient technology which facilitates faster multiplication of propagules with potent regeneration. In recent years, synthetic seed technology using encapsulation of nonembryogenic propagules derived under in vitro condition has become an important asset to micropropagation. Many genetically modified fruits and vegetables are already in the market in developed countries. It is a new aspect of biological and agricultural science which provides new tools and strategies in the struggle against world's food production problem.

\section{Biotechnological tool in fruit crop improvement}

\section{Tissue culture}

It is one of the most widely used techniques for rapid asexual in vitro propagation. This technique is economical in time and space affords greater output and provides disease free and elite propagules.

It also facilitates safer and quarantined movements of germplasm across nations. When the traditional methods are unable to meet the demand for propagation material this technique can produce millions of uniformly flowering and yielding plants. Micropropagation technology ensures true to type, rapid and mass multiplication of plants that possesses special significance in vegetatively propagated plant species. This technology has witnessed a huge expansion globally.

Some basic techniques of tissue culture, such as anther/microspore culture, somaclonal variation, embryo culture, and somatic hybridization, are being exploited to generate useful genetic variability for obtaining incremental improvement in commercial cultivars.

\section{Micropropagation}

Micropropagation of almost all the fruit crops is possible now. Production of virus free planting material using meristem culture has been made possible in many horticultural crop Strawberry is perhaps first fruit crop in which micropropagation technique has been standardized (Sharma and Singh, 1999). In vitro plants are more uniform, produce higher number of runners, have better survival in the field, and the fruit yield increase in $24 \%$ than plants propagated by the traditional method (Kikas et al., 2006). Banana is commercially propagated through tissue culture. The future of banana industry in the country is totally dependent upon control of BBTV disease. The ultimate choice is productions of diseasefree banana plants through in vitro techniques to replace infected fields. There are number of fruit crop in which propagation method is sexual. Some of them are dioecious i.e. male and female flower borne on different flowers. So through commercial point of view it is desirable to produce more female plant which, are the ones which bear fruits, this is possible only through tissue culture techniques. The grafting a very small shoot tip excised from an elite mother tree grafted onto a decapited rootstock seedling grown under aseptic condition. Murashige et al., (1972) made the first attempt in citrus and subsequently it was refined by Navarro et al., (1975).

\section{Embryo rescue}

Embryo rescue is another area, where plant breeders are able to rescue their crosses, which would otherwise abort. Culture of excised embryos of suitable stages of development can circumvent problems encountered in post zygotic incompatibility. This technique is highly significant in intractable and long duration horticultural species. Ovule culture in grapes (Singh et al., 1991) aids in developing hybrids, even in 
seedless grapes. Embryo rescue has helped in accelerating the pace of stenospermocarpic grape improvement and 'Sweet Scarlet' and 'Thomcord' are two of the seedless table grapevines, which were released using this technique (Annonymous, 2004).

\section{Anther/pollen culture}

Application of anther culture is obtaining haploids and homozygous diploids. It provides a short cut for obtaining pure lines.As tetraploid plants are produced in greater abundance in breeding programme, it may be feasible to culture their anther to produced useful diploids.

Regeneration of androgenic embryos in apple (Malus $x$ domestica Borkh.) via anther and microspore culture (Hofer, 2005) has been succeeded.

\section{In vitro mutagenesis}

Mutagens used physical (gamma rays, X-rays, UV rays) and chemical (EMS, MMS etc.).In fruit crops EMS and gamma rays are widely used. Notable example of in vitro mutagenesis in Banana variety Grand Nain explants used was shoot tips; mutagen source and dose were 80 Gy gamma rays developed improved cultivar Novaria-10 with improved trait early flowering and high keeping quality (Mac et al., 1996).

\section{Somatic hybridization}

It is crossing of crop plants through fusion of somatic cells. Protoplast of two cells is fused. It breaks the barriers of cross incompatibility among plant species and makes incompatible crosses possible. Somatic hybridization has been explored for the rootstock and scion improvement of citrus. In scion improvement production of allotetraploids $2 \mathrm{x} X 4 \mathrm{x}=3 \mathrm{x}$ (seedless) and direct $3 \mathrm{x}$ production whereas, in rootstock improvement, production of tetraploid rootstock for greater dwarfing effect, which is used in HDP. Gene transfer/wide somatic hybrids development of resistant rootstock through gene transfer from sexually incompatible or difficult to hybridized genera (Grosser et al., 2000). Somatic hybridization research of almost two decades in citrus is yielding fruit now.

\section{In vitro germplasm conservation}

In vitro conservation is of great significance in providing solutions and alternative approaches to overcoming constrains in management of genetic resources. Complete plants have been successfully regenerated from tissues cryopreserved at $-196^{\circ} \mathrm{C}$ in liquid $\mathrm{N}_{2}$ in several crops for several months to years (Ford et al., 2000; Panis et al., 2001; Halmagyi et al., 2004; Gupta and Reed, 2006; Ding et al., 2008). This method is now being practically used at several national and international germplasm banks.

In crops, which are propagated vegetatively and which produce recalcitrant seeds and perennial crops which are highly heterozygous seed storage is not suitable. In such crops especially, in vitro storage is of great practical importance. These techniques have successfully been demonstrated in a number of fruit crops and there are now various germplasm collection centers.

A portion of plants regenerated by tissue culture often exhibits phenotypic variation atypical of the original phenotype. Such variation, termed soma clonal variation may be heritable i.e. genetically stable and passed on to the next generation. Also, presently, synseed technology using encapsulation of non-embryogenic propagules derived under in vitro condition has become an important asset to micropropagation and in vitro conservation of planting material for long term. 


\section{Somaclonal variation}

Somaclonal variation (Larkin and Scowcroft, 1988) is considered a source of new plant genotypes for breeding, and advances at the tissue culture level have opened new possibilities for applications in viticulture. The advancements made in tissue culture techniques has made it possible to regenerate various horticultural species in vitro as micropropagation protocols for commercial scale multiplication are available for a wide range of crops. However, plant tissue culture may generate genetic variability i.e., somaclonal variations as a result of gene mutation or changes in epigenetic marks. The occurrence of subtle somaclonal variation is a drawback for both in vitro cloning as well as germplasm preservation. Somaclonal variation has provided a new and alternative tool to the breeders for obtaining genetic variability relatively rapidly and without sophisticated technology in horticultural crops, which are either difficult to breed or have narrow genetic base. Somaclonal variations are beneficial for creating variability and resistance to stresses (Table 1).

\section{Molecular marker}

A molecular marker is a DNA sequence that is readily detected and whose inheritance can easily be monitored. The phenotype is imperfect predictor of genotype. The phenotype is always expression of its genotype and environment interaction. Two plants having similar phenotype but genotype point of view they may be different. Application of molecular marker in fruit crops are genetic diversity assessment, estimation of genetic distance between cultivar and phylogenic analysis, detection of quantitative trait loci and marker assisted selection. Molecular marker is used in sex determination of dioecious plants at juvenile stage.Genetics of control mechanisms that underlies sex differentiation in date palm is not known. Sex of the plants becomes known only at the time of first flowering, which takes around 5 years. In comparison, molecular diagnosis (if available/feasible) promises quick and reliable identification of sex types very early when plantlets are growing in seedbeds. To develop such an assay, genomic DNA from 45 individual plants (25 female and 20 male) belonging to different varieties of date palm was subjected to PCR amplification using 100 RAPD and 104 ISSR (Dhawan et al., 2013). In papaya identification of female and hermaphrodite specific marker papaya sex determination by RAPD (Diwedi et al., 2014).

\section{Genetic diversity assessment}

Assessment of diversity has traditionally been made through morphological characters, chemical composition, and cytological characters, however, they have several limitations especially in perennial crops. Morphological characters are often limited in number, have complex inheritance pattern and are vulnerable to environmental conditions, hence it is desirable to develop alternative methods, which are rapid, reliable and more or less not influenced by environment. Therefore, in the recent past, rapid use of molecular markers has complemented the classical strategies. The use of DNA markers has enabled the characterization of genotypes independent of the influences of environmental growth conditions, physiological age of the plant and the type of tissue being analyzed. Molecular markers have been looked upon as tools with a large number of applications including localization of a gene and improvement of plant varieties by marker-assisted selection. Molecular markers thus, are excellent tools for analysis of genetic diversity and relationship (Table 2). Polymerase chain reaction (PCR) based random amplified polymorphic DNA (RAPD) 
markers have been extensively used in DNA finger printing. These DNA markers are generated by PCR amplification of random genomic segments with single primers (usually 10 nucleotides long) of arbitrary sequence (Williams et al., 1990). These markers are mostly dominant and detect variation in both coding and non-coding region of genome. RAPD analysis is technically simple and provides an approach to characterize different genotypes, thus to estimate genetic diversity which will further be useful in improvement of breeders.

Table.1 Stability of some somaclones to biotic stresses under field condition

\begin{tabular}{|c|c|c|c|c|}
\hline $\begin{array}{l}\text { Fruit } \\
\text { crop } \\
\text { /cultivar }\end{array}$ & $\begin{array}{l}\text { Somaclonal } \\
\text { variant }\end{array}$ & Resistant/tolerant to & $\begin{array}{l}\text { Field } \\
\text { performance }\end{array}$ & Reference \\
\hline $\begin{array}{l}\text { Prunus } \\
\text { persica }\end{array}$ & $\begin{array}{l}\text { S19-1 and S-156 } \\
\text { (Sunhigh) S122- } \\
1 \text { (Redhaven) } \\
\text { S122-1 }\end{array}$ & $\begin{array}{l}\text { Bacterial leaf spot } \\
\text { Pseudomonas syringae }\end{array}$ & $\begin{array}{l}* \mathrm{HR} \text { after } 3 \mathrm{yrs} \text { in } \\
\text { field } \\
\mathrm{HR} \text { resistance } \\
\text { compared } \\
\text { Redheaven }\end{array}$ & $\begin{array}{l}\text { Hammerschlag } \\
\text { et. al., } 1994\end{array}$ \\
\hline $\begin{array}{l}\text { Apple cv. } \\
\text { Green } \\
\text { Sleeves }\end{array}$ & - & $\begin{array}{l}\text { Fire blight (Erwinia } \\
\text { amylovora Strain } \mathrm{T})\end{array}$ & $\begin{array}{lr}60 \% & \text { less } \\
\text { symptoms } & \text { as } \\
\text { compared } & \text { parent } \\
\text { cultivar } & \end{array}$ & $\begin{array}{l}\text { Donovan et al., } \\
1994\end{array}$ \\
\hline $\begin{array}{l}\text { Citrus } \\
\text { limon }\end{array}$ & FS 01 and FS 11 & $\begin{array}{l}\text { Mal Secco (Phoma } \\
\text { tracheiphilla) }\end{array}$ & $\begin{array}{l}\text { Tolerence level } \\
\text { comparable to } \\
\text { Monachello (T) }\end{array}$ & $\begin{array}{l}\text { Gentile et al., } \\
1998\end{array}$ \\
\hline $\begin{array}{l}\text { Banana } \\
\text { cv. } \\
\text { William }\end{array}$ & CIEN BTA-03 & $\begin{array}{l}\text { Resistance to yellow and } \\
\text { black Sigatoka }\end{array}$ & $\begin{array}{l}\text { Similar } \\
\text { performance even } \\
\text { after } 5 \text { year of field } \\
\text { trails }\end{array}$ & $\begin{array}{l}\text { Unai et al., 2004; } \\
\text { Gimenez et al., } \\
2008\end{array}$ \\
\hline
\end{tabular}

Table.2 DNA markers for genetic diversity assessment in fruit crops

\begin{tabular}{|l|l|l|}
\hline Fruit & Marker type & Reference \\
\hline Apple & AFLP and RAPDs & $\begin{array}{l}\text { Coart } \text { et al., (2003); Botez } \text { et al., (2009); } \\
\text { Sestras } \text { et } \text { al., (2009) }\end{array}$ \\
\hline Avocado & Mini satellite DNA & Ashworth et al., (2003) \\
\hline Banana & RAPDs & Brown et al., (2009) \\
\hline Citrus & RFLP & Durham et al., (1992) \\
\hline Grapes & RFLP and SSRs & Bourquin et al., (1993) \\
\hline Mango & CpSSR and RAPDs & He et al., (2007) Marcela et al., (2009) \\
\hline Pistachio & Mini satellite marker & Riaz Ahmad et al., (2003) \\
\hline Cashew & RAPD and ISSR & Thimmappaiah et al., (2009) \\
\hline Pear & SSRs and AFLP & Sisko et al., (2009) \\
\hline
\end{tabular}


Table.3 Markers associated to main polygenic traits in fruit crops

\begin{tabular}{|c|c|c|c|}
\hline Fruit & Trait & Marker type & References \\
\hline Apple & Fire blight resistance & SCAR, SSR & Sylwia et al., (2009) \\
\hline Citrus & $\begin{array}{l}\text { Citrus leprosis virus } \\
\text { resistance }\end{array}$ & AFLP and RAPD & Bastianel et al.,(2009) \\
\hline Pear & Incompatibility & AFLP and SSR & Sun et al., (2009) \\
\hline Banana & Sugar content & RFLP & Ming et al., (2001) \\
\hline Grapes & $\begin{array}{l}\text { Seedlessness, Berry } \\
\text { Size, and Ripening } \\
\text { Date }\end{array}$ & $\begin{array}{l}\text { AFLP, SSR,RAPDs, } \\
\text { ISSRs and SCARs }\end{array}$ & Mejía et al., (2007) \\
\hline Strawberry & Day-neutrality & AFLP & Weebadde et al., (2008) \\
\hline Apricot & Plum Pox Virus & SSR & Soriano et al., (2007) \\
\hline
\end{tabular}

\section{Identification of QTLs}

Many important heritable characters are a consequence of the joint action of several genes. Such characters are often referred to as polygenic or quantitative. Several characters of plant species, among which are traits of agronomic importance, are inherited quantitatively. Yield, maturity date and drought tolerance are examples of such characters. The genetic loci for such characters have been referred to as quantitative trait loci (QTLs). The essential feature which makes feasible the finding and characterization of a QTL is its linkage with a known marker locus segregating with Mendelian ratios. DNA markers provide this opportunity by making it feasible to identify, map and measure the effects of genes underlying quantitative trait. In grape QTLs were used for features such as like critical photoperiod, growth cessation, or dormancy, bud break (BB) and winter hardiness (Table 3). Approximate positions of 28 major genes were mapped in different populations of peach (orange background), almond (yellow background) and Myrobalan plum (green background) on the framework of the Prunus reference map. Gene abbreviations correspond to: $Y$, peach flesh colour; Sharka, plum pox virus resistance; $M i$, nematode resistance from peach; $D$, almond shell hardness; $B r$, broomy plant habit; $D l$, double flower; $C s$, flesh color around the stone; $A g$, anther color; $P c p$, polycarpel; $F c$, flower color; $L b$, blooming date; $F$, flesh adherence to stone; $D$, non-acid fruit in peach, $S k$, bitter kernel; $G$, fruit skin pubescence; $N l$, leaf shape; $D w$, dwarf plant; $P s$, male sterility; $S c$, fruit skin color; $G r$, leaf colour; $M a$, nematode resistance from Myrobalan plum; $E$, leaf gland shape; $S f$, resistance to powdery mildew. Genes $D l$ and $B r$ are located on an unknown position of $\mathrm{G} 2$.

\section{Marker assisted selection}

The use of molecular markers can greatly accelerate the pace of selection in fruit crops with inherent long juvenile period and when trait under study is controlled by the recessive gene and incorporating more than one gene 
for disease resistance. Presently, the markers linked to resistance to Dagger nematode (Xiphinema index) and pierce disease are being routinely used at University of California in the breeding programs aimed at improving grapevine rootstock. $(\mathrm{Xu}$ et al., 2008).The resistance to most successful resistance gene $(\mathrm{V} f)$ for scab has been overcome in apple by new race pathogen (Gygax et al.,2004).

\section{Genetic transformation}

Process of transfer, integration and expression of transgenes in the host cells is known as genetic transformation. Resistant to biotic stress for example citrus decline, CTV, greening, papaya ring spot virus resistance, plum pox virus etc. Higher tolerance to abiotic stress i.e. salinity, flood, drought etc., shortening the juvenile growth phase and quality improvement such as shelf life improvement and edible vaccine.

\section{Shelf life improvement}

The compositional similarity of the transgenic papayas with delayed ripening trait with the non-transgenic control papayas. Fruit characteristics such as days to maturity, fruit weight and total soluble sugars were similar for both transgenic and control papaya trees (Cabanos, et al., 2014).

Two ACC oxidase genes, CpACO1 and $\mathrm{CpACO} 2$ are reported and $\mathrm{CpACO} 1$ is associated with late stage fruit ripening and leaf senescence whereas $\mathrm{CpACO} 2$ is induced before colors break (Chen et al., 2003). Two of the ripening-related genes MaMads-rin and MaExp2 are used for banana transformation in order to increase shelf-life and fruit quality Liu et al., (2009). Juan et al., (2009) have shown that PG plays a significant role in strawberry ripening. Two ripening-related PG genes, FaPG1 and FaPG2 identified for regulation of fruit ripening. Using tobacco rattle virus-induced gene silencing, the down regulation of FaSS1 transcripts significantly delayed fruit ripening, as evidenced by the changes of firmness, and soluble sugar and anthocyanin contents, as well as the transcripts of several ripening-related genes, including PE1, PL1, XYL2, CHS, CHI and DFR. Furthermore, the mRNA expression level of FaSS1 was inhibited by abscisic acid or sucrose, but not by glucose after fruit disc incubation in vitro (Cheng et al., 2017). The two banana E class (SEPALLATA3 [SEP3]) MADS box genes, MaMADS1 and MaMADS2, homologous to the tomato (Solanum lycopersicum) RIN-MADS ripening gene. Transgenic banana plants repressing either gene (via antisense or RNA interference [RNAi]) were created and exhibited specific ripening delay and extended shelf-life phenotypes, including delayed color development and softening (Tomeret al.,2016).

\section{Disease resistance}

A viral diseases papaya ring spot virus came to Hawaii in the 1940's and had wiped out papaya production on Oahu by the 1950's. Transgenicpapaya was developed through coat protein mediated gene transformation. The two transgenic varieties were developed i.e. Sun Up and Rainbow, those are resistant to Papaya ring spot virus, which revolutionized the papaya cultivation in Hawaii (Gonsalves, 2000).

Plum pox virus causes fruit deformation and reduced quality, premature fruit drop, leaf chlorosis, tree decline and death in severe infections or co-infections with other viruses. Honey Sweet an improved cultivar of plum was developed using mechanism of RNAi silencing, which was resistant to virus (Ravelonandro et al., 2000). 


\section{Future prospect}

Plant biotechnology has the potential to play a key role in the sustainable production of fruit crops. However, there is enormous potential for genetic manipulation of some vegetative propagated fruit crops in order to improve their disease and pest resistance. The use of appropriate constructs may allow the production of nematode, fungal, bacterial and virus resistant plants in a significantly shorter period of time than using conventional breeding, especially if several traits can be introduced simultaneously. It may also be possible to incorporate other characteristics such as drought tolerance, thereby extending the geographic spread of some fruit crops for production, and thus contributing substantially to enhanced food security and poverty alleviation. However, high caution is required for biosafety experiments and potential risk assessment bearing in mind that these are consumed by most humans and mainly by children.

\section{References}

Anonymous (2004). FPS Grape Program Newsletter October, 2004. Foundation Plant Services, pp:4.

Ashworth, V. E. and M. T. Clegg (2003). Microsatellite Markers in Avocado (Prunus americana Mill.): Genealogical Relationships Among Cultivated Avocado Genotypes Journal of Heredity 94:407-415.

Bastianel, M., L. Cristofani-Yaly, A. C. M. Oliveira, J. Freitas-Astúa, A. Antonio, G. M. Franco, D. V. Resende, V. Rodrigues and M. A. Machado (2009). Quantitative trait loci analysis of citrus leprosis resistance in an interspecific backcross family of (Citrus reticulata Blanco $\times C$. sinensis L. Osbeck) $\times \mathrm{C}$. sinensis L. Osb. Euphytica 169:101111.
Bhat, Z.A., Dhillon W.S., Rashid R., Bhat, J.A., Dar W.A., Ganaie M.Y (2010). The role of Molecular Markers in Improvement of Fruit Crops. Not Sci Biol 2 (2) 22-30.

Botez, C., R. Sestras, M. Ardelean, D. Pamfil, B. Patrascu and A. Sestras (2009). Phenotypic Selection Assisted by Molecular Markers for Scab Resistance in Apple. Acta Hort. 814:771-776.

Botstein, J. O., A. Sonko, L. Otten and B. Walter (1993). RFLP molecular taxonomy in Vitis vinifera L. Theor. Appl. Genet. 87:431-38.

Bourquin, J. C., A. Sonko, L. Otten and B. Walter (1993). RFLP molecular taxonomy in Vitis vinifera. Theor. and Appl. Genet. 87:431-38.

Cerrone, S. C., Andres, G. S., Roberta, N. G., Simeona, V. S. and Evelyn, M. T. M. 2003. Compositional analysis of transgenic papaya with delayed ripening trait. Philippines Agricultural Scientist, 96(4): 331-339

Chen Y.T., Lee, Y.R., Yang, C.Y., Wang, Y. T., Yang, S. F., Shaw, J. F. 2003. A novel papaya ACC oxidase gene (CP$\mathrm{ACO} 2$ ) is associated with late stage fruit ripening and leaf senescence. Plant Science, 164:531-40.

Cheng Zhao, Li-Na Hua, Xiao-Feng Liu,YuZhong Li, Yuan-Yue Shen, Jia-Xuan Guo.2017.Sucrose synthase FaSS1 plays an important role in the regulation of strawberry fruit ripening. Plant Growth Regulaters, 81:175-181.

Coart, E., X. Vekemans, M. J. M. Smulders, I. Wagner, J. Van Huylenbroeck, E. Van Bockstaele and I. Roldán-Ruiz (2003). Genetic variation in the endangered wild apple (Malussylvestris L. Mill.) in Belgium as revealed by amplified fragment length polymorphism and microsatellite markers. Mol. Ecology 12:845-857.

Dhawan, C., Kharb, P. and Sharma R. (2013). 
Development of male specific SCAR Marker in Date palm (Phoenix dactylifera L.). Tree Genetics and Genomes. 9: 1143-1150.

Ding, F., S. Jin, N. Hong, Y. Zhong, Q. Cao, G. Yi, and G. Wang. 2008. Vitrification cryopreservation, an efficient method for eliminating Candidatus Liberobacter asiaticus, the citrus Huanglongbing pathogen, from in vitro adult shoot tips. Plant Cell Rep. 27:241-250.

Donovan, A. M., Morgan, R., ValobraPiagnani, C., Ridout, M. S., James, D. J., and Garrett, C. E. (1994). Assessment of somaclonal variation in apple. I. Resistance to the fire blight pathogen, Erwinia amylovora. Journal of horticultural science, 69(1), 105-113.

Dwivedi S. Pandey, P., Shamin M.D., Srivastva D and Singh KN (2014). Identification of female and Hermaphrodite specific marker and diversity assessments in Papaya (Carica papaya) cultivars. Indian J. Agric Biochem. 27(2): 129-132.

Ford, C.S., N.B. Jones, and J. Van Staden. 2000. Optimization of a working cryopreservation protocol for Pinus patula embryogenic tissue. In Vitro Cell. Dev. Biol. Plant 36:366-399.

Gentile, A., Deng, Z. N., Tribulato, E., Vardi, A., Albanese, G., Grimaldi, V., and Catara, A. (1998, November). Evaluation of lemon somaclones for tolerance to mal secco disease by artificial inoculation. In First International Citrus Biotechnology Symposium 535 (pp. 259-263).

Giménez, C., de García, E., and Haddad, O. (2008). Genetic and resistance stability to Black Sigatoka disease during micropropagation of Musa CIEN BTA03 somaclonal variant. Phyton (Buenos Aires), 65.

Gonsalves D. (2004). Transgenic Papaya in Hawaii and Beyond. AgBio Forum,
7(1\&2): 36-40.

Grosser, J.W., Ollitrault, P. and OlivaresFuster, O. (2000). Somatic hybridization in citrus: An effective tool to facilitate variety improvement. In Vitro Cell. Dev. Biol.-Plant 36 (6): 434449.

Guo W W, Prasad D, Serrario P, Gmitter FG $\mathrm{Jr}$ and Grosser JW (2004). Citrus somatic hybridization with potential for direct tetraploid scion cultivar development. J. Hort. Sci. Biotech. 79: 400-05.

Gupta, S., and B.M. Reed. 2006. Cryopreservation of shoot tips of blackberry and raspberry by encapsulation-dehydration and vitrification. Cryo Letters 27: 29-42.

Gygax, M., Gianfranceschi, L., Liebhard, R., Kellerhals, M., Gessler, C., and Patocchi, A. (2004). Molecular markers linked to the apple scab resistance gene Vbj derived from Malusbaccatajackii. Theoretical and Applied Genetics, 109(8), 1702-1709.

Halmagyi, A., C. Deliu, A. Coste, M. Keul, O. Cheregi, and V. Cristea. 2004. Vitrification of potato shoot tips for germplasm cryopreservation. Contributii Botanice. 39:187-193.

Hammerschlag, F., Ritchie, D., Werner, D., Hashmil, G., Krusberg, L., Meyer, R., and Huettel, R. (1994). In vitro selection of disease resistance in fruit trees. Genetic Improvement of Horticultural Crops by Biotechnology 392, 19-26.

He, X., G. Yong-zeb, L. Yang-ruia and O. Shi-jinb (2007). Assessment of the Genetic Relationship and Diversity of Mango and Its Relatives by cpISSR Marker. Agricultural Sciences in China 6:137-142.

Hofer M. (2005).Regeneration of androgenic embryos in apple (Malus xdomestica Brokh.) via anther and microspore 
culture. Acta Physiologiae Plantarum. 27(4) 709-716.

Hwang S.C. and Ko W.H. (2004). Cavendish Banana Cultivars Resistant to Fusarium Wilt Acquired through Somaclonal Variation in Taiwan. Plant Disease 88(6): 580-587.

Juan, A. García-Gago, Sara, P., Juan, MuñozBlanco., Miguel, A. Q. and José, A. M. 2009. The polygalacturonase FaPG1 gene plays a key role in strawberry fruit softening. Plant Signaling and Behavior, 4(8): 766-768

Kikas, A. Libek, A. and Vasar, V. (2006). Influence of micropropagation on the production of strawberry runner plants, yield and quality. Acta Hort. 708:241244.

Liu, J., Xu, B., Hu, L., Li, M., Su, W., Wu, J. 2009. Involvement of a banana MADSbox transcription factor gene in ethylene induced fruit ripening. Plant Cell Reports, 28:103-11.

Mac C, Ho Y,W., Pan YP and Ibrahim R (1996). Novaria- a new banana mutant induced by gamma irradiation. Infomusa $\mathrm{J}: 35-36$.

Marcela, D. M., S. G. Ingrid, R. G. E. Manuel and H. Jaramillo (2009). Analysis of diversity among six populations of Colombian mango (Mangifera indica $\mathrm{L}$. cv. Hilacha) using RAPDs markers. Electronic Journal of Biotech. 12:1-6.

Mejía, N., M. Gebauer, L. Muñoz, N. Hewstone, C. Muñoz and P. Hinrichsen (2007). Identification of QTLs for Seedlessness, Berry Size, and Ripening Date in a Seedless $x$ Seedless Table Grape Progeny. Am. J. Enol. Vitic. 58:499-507.

Ming, R., S. C. Liu, P. H. Moore, J. E. Irvine and A. H. Paterson (2001). QTL Analysis in a Complex Autopolyploid: Genetic Control of Sugar Content in Sugarcane. Genome Res. 11: 20752085.
Murashige, T. and Skoog, F. (1962). A revised medium for rapid growth and bioassay with tobacco tissue cultures. Physiol. Plant. 15:473-497.

Navarro L., Roistacher C.N., Murashige T., 1975. Improvement of shoot-tip grafting in vitro for virus free citrus, Americ. Soc. Hort. Sci. 100: 471-79.

Panis, B., R. Swennen, and F. Engelmann. (2001). Cryopreservation of plant germplasm. ActaHorti. 560:79-86.

Ramming DW (1990). The use of embryo culture in fruit breeding. Hort. Science 25(4):393-98.

Ravelonandro, M., Scorza R., Callahan, A., Levy L., Jacquet C., Monsion M., Damsteegt V., The use of transgenic fruit trees as a resistance strategy for virus epidemics: the plum pox (sharka) model. Virus Research 71, 63-69.

Riaz, A., L. Ferguson and M. S. Stephen (2003). Identification of Pistachio (Pistacia vera L) Nuts with microsatellite markers. J. Amer. So. Hort. Sci. 128:898-903.

Scowcroft, W. R., and Larkin, P. J. (1988). Somaclonal variation. Applications of Plant Cell and Tissue Culture, 21-35.

Sestras, R., D. Pamfil, M. Ardelean, C. Botez, A. Sestras, C. Dan and L. Mihalte (2009). Use of Phenotypic and MAS Selection Based on Bulk Segregant Analysis for Study of Genetic Variability Induced by Artificial Hybridization on Apple. Notulae Botanicae Horti Agrobotanici ClujNapoca 37(1):273-277.

Sharma, R.R. and Singh S.K. (1999). Strawberry cultivation- a highly remunerative farming enterprise. Agro India. 3(2):29-31.

Singh, Z.S., J.S. Brar, and S.S. Gosal. 1991. Ovule culture of seedless grapes (Vitis vinifera L.) cv. Perlette. Acta Horticulture 300:325-329.

Sisko, M., B. Javornik, A. Siftar and A. 
Ivancic (2009). Genetic relationships among Slovenian pears assessed by molecular markers. J. Amer. Soc. Hort. Sci. 134:97-108.

Soriano, J. M., E. M. Vera-Ruiz, S. Vilanova, J. Martínez-Calvo, G. Llácer, M. L. Badenes and C. Romero (2007). Identification and mapping of a locus conferring plum pox virus resistance in two apricot-improved linkage maps. Tree Genetics and Genomes 4:391-402

Sylwia, K. P., L. Mariusz and K. Malgorzata (2009). Molecular screening of apple (Malus $\mathrm{x}$ domestica) cultivars and breeding clones for their resistance to fire blight. Journal of Fruit and Ornamental Plant Res. 17:31-43.

Thimmappaiah, W. G., D. Santhosh Shobha and G. S. Melwyn (2009). Assessment of genetic diversity in cashew germplasm using RAPD and ISSR markers. Scientia Hort. 120:411-417

Tomer, E., Esther, Y., Lydia, Q., Fei, Z., Julia, V., Eli, K., James, J., Giovannoni and Haya, F. 2016. Banana MaMADS transcription factors are necessary for fruit ripening and molecular tools to promote shelf-life and food security. Plant Physiology, 171:380-391.

Unai, Emaldi, Iselen Trujillo, and Eva de García. "Comparison of characteristics of bananas (Musa sp.) from the somaclone CIEN BTA-03 and its parental clone Williams. Fruits59 (4) 257-263.

Weebadde, C. K., D. Wang, C. E. Finn, K. S. Lewers, J. J. Luby, J. Bushakra, T. M. Sjulin and J. F. Hancock (2008). Using a linkage mapping approach to identify QTL for day-neutrality in the octoploid strawberry. Plant Breeding 127 94-101.

Williams, J. G., Kubelik, A. R., Livak, K. J., Rafalski, J. A., and Tingey, S. V. (1990). DNA polymorphisms amplified by arbitrary primers are useful as genetic markers. Nucleic acids research, 18(22), 6531-6535.

Xu K, Riaz S, Roncoroni NC, Jin Y, Hu R, Zhou R and Walker MA (2008). Genetic and QTL analysis of resistance to Xiphenema index in a grapevine crop. Theor. Appl. Genet. 116:305-11.

\section{How to cite this article:}

Anuradha, Subhash Chander and Arvind Malik. 2017. Biotechnology a Modern Tool for Fruits Production - A Review. Int.J.Curr.Microbiol.App.Sci. 6(11): 1902-1912. doi: https://doi.org/10.20546/ijcmas.2017.611.226 